\title{
KAJIAN HUKUM JAMINAN HAK TANGGUNGAN YANG DILELANG TANPA PROSES PERMOHONAN LELANG EKSEKUSI KE KETUA PENGADILAN NEGERI
}

\author{
Catur Budi Dianawati', Amin Purnawan ${ }^{* *}$ \\ * Mahasiswa Program Magister (S2) Kenotariatan Fakultas Hukum UNISSULA, Semarang, email : \\ dianataurus13@yahoo.com \\ ** Dosen Fakultas Hukum UNISSULA, Semarang email: amin.p@unissula.ac.id
}

\section{ABSTRACT}

The facts on the field showed that the creditors often conducted public auction without first applying to the Chairman of the District Court, yet directly to the auction office made under article 6 of law number 4 year 1996 about mortgage right upon land and things related to it. The following were the problem formulation of the study; (1) how should the procedure for public auction be made according on the law number 4 year 1996 about mortgage right upon the land and things related to it? (2) Why did the creditors auction the guarantee of the dependent right without experiencing the process of proposing the permit for the auction to the Chairman of the District Court? (3) What would the legal consequences be towards the guarantee of the mortgage right auctioned without the process of getting the permit from the Chairman of the District Court?

Method used in this study was adopted from the approach of juridical empirics (empirical legal research). The collected data were processed and verified using descriptive analysis to which it is frequently intended to research for human, condition and other phenomena.

Based on the result in this study and the result from discussion about the procedure of public auction towards the guarantee of mortgage rights according to the law Number 4 Year 1996 about mortgage rights upon land and things related to it to which it is arranged in the provision of article 26. It is observed that as long as there is no rules of legislation specifically governs the execution of mortgage rights, the procedure of this execution should comply with hypothec execution as arranged in article 224 in the refurbished Indonesia Regulation (Het Herziene Indonesisch Reglement/HIR). Article 6 of the law Number 4 Year 1996 about mortgage right upon land and things related to it where it gives the right to the creditors holding the first mortgage right to sell the object on his own power, in case, the debtors violates the commitment, became the reasons why they auctioned the guarantee of the right without proposing the permit for the auction to the Chairman of the District Court. The legal consequence towards the guarantee of the mortgage right auctioned without experiencing the process of proposing the permit for the auction to the Chairman of the District Court was null and void.

Keywords : : Guarantee of Mortgage Right, Public Auction, Chairman of District Court

\section{PENDAHULUAN}

Kredit menurut Pasal 1 angka 2 Undang-Undang Nomor 7 Tahun 1992 tentang Perbankan sebagaimana telah diubah dengan Undang-Undang Nomor 10 Tahun 1998 tentang Perubahan atas UndangUndang Nomor 7 Tahun 1992 tentang Perbankan adalah:

"penyediaan uang atau tagihan yang dapat dipersamakan dengan itu, berdasarkan persetuju- an atau kesepakatan pinjam meminjam antara Bank dengan pihak lain yang mewajibkan pihak peminjam untuk melunasi hutangnya setelah jangka waktu tertentu dengan jumlah bunga".

Pemberian kredit oleh lembaga keuangan kepada masyarakat akan diikuti dengan suatu hubungan hukum dalam bentuk perjanjian berupa perjanjian kredit. Perjanjian merupakan kesepakatan antara dua orang atau dua pihak, mengenai hal-hal pokok yang menjadi objek dari perjanjian. 
Kesepakatan itu timbul karena adanya kepentingan dari masing-masing pihak yang saling membutuhkan. Menurut Subekti, kata sepakat berarti suatu persesuaian paham dan kehendak antara dua pihak. Berdasarkan pengertian kata sepakat tersebut berarti apa yang dikehendaki oleh pihak yang satu, juga dikehendaki oleh pihak yang lain, meskipun tidak sejurusan tetapi secara timbal balik kedua kehendak itu bertemu satu sama lain. ${ }^{1}$

Kredit atau pembiayaan yang diberikan oleh bank mengandung risiko, sehingga dalam setiap pemberian kredit atau pembiayaan berdasarkan prinsip syariah yang sehat dan berdasarkan prinsip kehati-hatian. Prinsip kehati-hatian yang harus diperhatikan oleh bank adalah watak, kemampuan, modal, agunan, dan prospek usaha dari para calon debitor, yang dikenal dengan "the five $C$ of credit analysis" atau di kenal dengan prinsip $5 \mathrm{C}^{\prime}{ }^{2}{ }^{2}$ Pada prinsipnya konsep 5 C's ini akan dapat memberikan informasi mengenai itikad baik (willingness to pay) dan kemampuan membayar (ability to pay) debitor dalam melunasi kembali pinjaman berikut dengan bunga dan beban lainnya. ${ }^{3}$ Prinsip-prinsip penilaian kredit analisis $5 C^{\prime}$, tersebut meliputi: ${ }^{4}$

1. Character

2. Capacity (capability)

3. Capital

4. Collateral

5. Condition

Collateral atau jaminan merupakan salah satu aspek penting yang dapat memberikan perlindungan terhadap risiko yang mungkin timbul dalam pemberian kredit oleh bank. Bank memperoleh kepastian pengembalian kredit yang telah diberikan ke debitornya jika mereka wanprestasi melalui pemberian jaminan oleh debitor. Jaminan yang diberikan debitor dapat berupa barang (benda) sehingga merupakan jaminan kebendaan dan atau berupa janji penanggungan utang sehingga merupakan jaminan perorangan. Kewajiban untuk menyerahkan jaminan oleh pihak debitpr dalam

${ }^{1}$ R. Soebekti, 2010, Aneka Perjanjian, Citra Aditya Bakti: Bandung, 1995, hlm. 26.

${ }^{2}$ Rachmadi Usman, 2001, Aspek-Aspek Hukum Perikatan Perbankan Di Indonesia, Gramedia Pustaka: Jakarta, hlm 246

${ }^{3}$ Ibid

${ }^{4}$ Widjanarto, 2013, Hukum dan Ketentuan Perbankan Di Indonesia, Pustaka Utama Grafiti: Jakarta,hlm 92. rangka pinjaman uang sangat terkait dengan kesepakatan di antara pihak-pihak yang melakukan pinjam-meminjam uang. ${ }^{5}$

Jaminan kebendaan ialah jaminan yang berupa hak mutlak atas sesuatu benda, yang mempunyai ciri-ciri: mempunyai hubungan langsung atas benda tertentu dari debitur, dapat dipertahankan terhadap siapapun, selalu mengikuti bendanya (droit de suite) dan dapat dipindahtangankan atau dialihkan kepada pihak lain. Sedangkan jaminan perorangan ialah jaminan yang menimbulkan hubungan langsung pada perorangan tertentu, hanya dapat dipertahankan terhadap debitur tertentu, terhadap harta kekayaan debitur pada umumnya. ${ }^{6}$

Khusus jaminan benda tidak bergerak yang menyangkut tanah yang paling diminati bank pemberi kredit adalah tanah yang dapat dibuktikan kepemilikannya dengan menunjukkan sertipikat karena tidak mudah dipindah tangankan, harganya cenderung meningkat, dan mempunyai tanda bukti hak. Menurut Liliawati, Undang-Undang Republik Indonesia Nomor 4 Tahun 1996 yang mengatur tentang hak tanggungan atas tanah beserta bendabenda yang berkaitan dengan tanah lahir untuk memenuhi kebutuhan masyarakat tersebut. ${ }^{7}$

Tujuan pemasangan hak tanggungan atas sertipikat tanah adalah memudahkan pihak kreditur untuk melakukan eksekusi hak tanggungan jika debitur wanprestasi. Hal ini karena dalam sertipikat hak tanggungan memuat irah-irah "DEMI KEADILAN BERDASARKAN KETUHANAN YANG MAHA ESA" yang membuat sertipikat hak tanggungan memiliki kekuatan eksekutorial yang sama dengan putusan pengadilan yang telah memperoleh kekuatan hukum tetap (Pasal 14 ayat 2 Undang-Undang Nomor 4 Tahun 1996 Tentang Hak Tanggungan Atas Tanah Beserta Benda-Benda Yang Berkaitan Dengan Tanah).

${ }^{5}$ M.Bahsan, 2017, Hukum Jaminan dan Jaminan Kredit Perbankan Indonesia, Raja Grafindo Persada: Jakarta, hlm. 2.

${ }^{6}$ Sri Soedawi Masjchoen Sofwan,2003, Hukum Jaminan di Indonesia, Pokok-pokok Hukum Jaminan dan Jaminan Perorangan,Cetakan ke-3, Liberty Offset: Yogyakarta, hlm. 46-47

${ }^{7}$ Eugema Liliawati Mulyono,2003, Tinjauan Yuridis Undang-undang Nomor 4 Tahun 1996 tentang Hak Tanggungan Dalam Kaitannya Dengan Pemberian Kredit Oleh Perbankan, Harvarindo: Jakarta,hlm 1 
Dalam hal ternyata debitur wanprestasi dan tidak mampu memenuhi kewajiban, maka berdasarkan Pasal 6 Undang-Undang Nomor 4 Tahun 1996 Tentang Hak Tanggungan Atas Tanah Beserta Benda-Benda Yang Berkaitan Dengan Tanah dinyatakan :

Apabila debitor cidera janji, pemegang Hak Tanggungan pertama mempunyai hak untuk menjual obyek Hak Tanggungan atas kekuasaan sendiri melalui pelelangan umum serta mengambil pelunasan piutangnya dari hasil penjualan tersebut.

Secara khusus dalam Pasal 20 ayat (1) UndangUndang Nomor 4 Tahun 1996 Tentang Hak Tanggungan Atas Tanah Beserta Benda-Benda Yang Berkaitan Dengan Tanah menyatakan :

(1) Apabila debitor cidera janji, maka berdasarkan:

a. hak pemegang Hak Tanggungan pertama untuk menjual obyek Hak Tanggungan sebagaimana dimaksud dalam Pasal 6, atau

b. titel eksekutorial yang terdapat dalam sertifikat Hak Tanggungan sebagaimana dimaksud dalam Pasal 14 ayat (2), obyek Hak Tanggungan dijual melalui pelelangan umum menurut tata cara yang ditentukan dalam peraturan perundang-undangan untuk pelunasan piutang pemegang Hak Tanggungan dengan hak mendahulu dari pada kreditor-kreditor lainnya.

Menurut Pasal 20 ayat (1) huruf b UndangUndang Nomor 4 Tahun 1996 Tentang Hak Tanggungan Atas Tanah Beserta Benda-Benda Yang Berkaitan Dengan Tanah, obyek Hak Tanggungan dijual melalui pelelangan umum menurut tata cara yang ditentukan dalam peraturan perundangundangan untuk pelunasan piutang pemegang Hak Tanggungan dengan hak mendahulu dari pada kreditor-kreditor lainnya.

Berdasarkan ketentuan Pasal 26 UndangUndang Nomor 4 Tahun 1996 Tentang Hak Tanggungan Atas Tanah Beserta Benda-Benda Yang Berkaitan Dengan Tanah, selama belum ada peraturan perundang-undangan yang mengaturnya, dengan memperhatikan ketentuan dalam Pasal 14, peraturan mengenai eksekusi hypotheek yang ada pada saat mulai berlakunya Undang-Undang ini, berlaku terhadap eksekusi Hak Tanggungan.

Fakta di lapangan menunjukkan bahwa seringkali kreditur melakukan lelang eksekusi tanpa terlebih dahulu mengajukan permohonan ke Ketua Pengadilan Negeri, tetapi langsung ke Kantor lelang dengan dasar Pasal 6 Undang-Undang Nomor 4 Tahun 1996 Tentang Hak Tanggungan Atas Tanah Beserta Benda-Benda Yang Berkaitan Dengan Tanah, sementara menurut Pasal 224 Reglemen Indonesia yang Diperbarui (Het Herziene Indonesisch Reglement, Staatsblad 1941-44) dan Pasal 258 Reglemen Acara Hukum Untuk Daerah Luar Jawa dan Madura (Reglement tot Regeling van het Rechtswezen in de Gewesten Buiten Java en Madura, Staatsblad 1927-227), sebelum mengajukan lelang eksekusi kreditur harus menghadap Ketua Pengadilan Negeri. Hal ini menunjukkan adanya kesenjangan antara das sollen (cita-cita) dengan das sein (kenyataan).

Permasalahan dalam penelitian ini dapat dirumuskan sebagai berikut: Bagaimana prosedur eksekusi lelang terhadap jaminan hak tanggungan menurut Undang-Undang Nomor 4 Tahun 1996 Tentang Hak Tanggungan Atas Tanah Beserta Benda-Benda Yang Berkaitan Dengan Tanah ? Mengapa kreditor melelang jaminan hak tanggungan tanpa proses permohonan lelang eksekusi ke Ketua Pengadilan Negeri ? Bagaimana akibat hukum terhadap jaminan hak tanggungan yang dilelang tanpa proses permohonan lelang eksekusi ke Ketua Pengadilan Negeri?

\section{METODE PENELITIAN}

Dalam penelitian ini penelitian hukum yang digunakan adalah pendekatan yuridis empiris (empiric legal research). ${ }^{8}$ penelitian hukum yang didasarkan pada penelitian lapangan atau penelitian data primer untuk memahami gejala hukum yang mencakup dalam masyarakat dikaitkan dengan asasasas hukum, norma hukum, peraturan perundangundangan, ${ }^{9}$

Spesifikasi penelitian yang digunakan bersifat deskriptif analitis, yaitu penelitian yang dimaksudkan

\footnotetext{
${ }^{8}$ Zainuddin Ali,2010, Metode Penelitian Hukum, Sinar Grafika: Jakarta, hlm 19

${ }^{9}$ Soerjono Soekanto dan Sri Mamudji, 2001, Penelitian Hukum Normatif suatu Tinjauan Singkat, Radja Grafindo Persada: Jakarta, hlm 11
} 
untuk manusia, keadaan/gejala-gejala lainnya. ${ }^{10}$ Analisis data dilakukan dengan menggunakan metode analisis kualitatif. dikaitkan dengan jaminan hak tanggungan yang dilelang tanpa proses permohonan lelang eksekusi ke Ketua Pengadilan Negeri.

\section{HASIL PENELITIAN DAN PEMBAHASAN}

\section{Prosedur Eksekusi Lelang Terhadap Jaminan Hak Tanggungan}

Hak Tanggungan memberikan kedudukan yang diutamakan kepada kreditor pemegang hak tanggungan terhadap kreditor-kreditor lain. Jika debitor cidera janji, kreditor pemegang Hak Tanggungan berhak menjual melalui pelelangan umum tanah yang dijadikan jaminan menurut peraturan perundang-undangan yang bersangkutan, dengan hak mendahului daripada kreditor-kreditor yang lain. Kedudukan diutamakan tersebut sudah barang tentu tidak mengurangi preferensi piutangpiutang Negara menurut ketentuan-ketentuan hukum yang berlaku.

Apabila debitor cidera janji, maka berdasarkan hak pemegang Hak Tanggungan pertama untuk menjual obyek Hak Tanggungan sebagaimana, atau title eksekutorial yang terdapat dalam sertipikat Hak Tanggungan sebagaimana dimaksud dalam Pasal 14 ayat (2), obyek Hak Tanggungan dijual melalui pelelangan umum menurut cara yang ditentukan dalam peraturan perundangundangan untuk pelunasan piutang pemegang Hak Tanggungan dengan hak mendahului daripada kreditor-kreditor lainnya.

Eksekusi jaminan hak tanggungan pada dasarnya merupakan langkah terakhir yang dilakukan kreditor selaku penerima hak tanggungan apabila debitor selaku pemberi hak tanggungan cidera janaji. ${ }^{11}$ Eksekusi jaminan hak tanggungan baru bisa dilaksanakan, apabila debitor benar-benar telah tidak mampu memenuhi kewajibannya membayar angsuran kredit atau hutang atau ;pinjaman kepada

${ }^{10}$ Bambang Sunggono,2007, Metodologi Penelitian Hukum, Rajawali Press: Jakarta, hlm 36

11 Moch Anshori,Lelang Berdasarkan Pasal 6 UUHT Batal Demi Hukum, Direktur Eksekutif LPK Komnas PKPU dan Direktur Eksekutif Entitas Hukum Indonesia, www.entitashukumindonesia.blogspot.com, kreditor berdasarkan perjanjian kredit atau perjanjian hutang atau perjanjian pinjaman yang telah disepakati bersama. Pada posisi demikian, kreditor dalam melaksanakan eksekusi jaminan hak tanggungan harus tunduk pada ketentuan UndangUndang Nomor 4 Tahun 1996 tentang Hak Tanggungan atas Tanah Beserta Benda-Benda yang Berkaitan dengan Tanah.

Berkaitan dengan prosedur eksekusi Hak Tanggungan, diatur dalam ketentuan Pasal 20 Undang-Undang Nomor 4 Tahun 1996 tentang Hak Tanggungan atas Tanah Beserta Benda-Benda yang Berkaitan dengan Tanah. Pasal 20 Undang-Undang Nomor 4 Tahun 1996 tentang Hak Tanggungan atas Tanah Beserta Benda-Benda yang Berkaitan dengan Tanah menyatakan:

(1) Apabila debitor cidera janji, maka berdasarkan:

a. hak pemegang Hak Tanggungan pertama untuk menjual obyek Hak Tanggungan sebagaimana dimaksud dalam Pasal 6, atau

b. titel eksekutorial yang terdapat dalam sertifikat Hak Tanggungan sebagaimana dimaksud dalam Pasal 14 ayat (2), obyek Hak Tanggungan dijual melalui pelelangan umum menurut tata cara yang ditentukan dalam peraturan perundang-undangan untuk pelunasan piutang pemegang Hak Tanggungan dengan hak mendahulu dari pada kreditor-kreditor lainnya.

(2) Atas kesepakatan pemberi dan pemegang Hak Tanggungan, penjualan obyek Hak Tanggungan dapat dilaksanakan di bawah tangan jika dengan demikian itu akan dapat diperoleh harga tertinggi yang menguntungkan semua pihak.

(3) Pelaksanaan penjualan sebagaimana dimaksud pada ayat (2) hanya dapat dilakukan setelah lewat waktu 1 (satu) bulan sejak diberitahukan secara tertulis oleh pemberi dan/atau pemegang Hak Tanggungan kepada pihak-pihak yang berkepentingan dan diumumkan sedikit-dikitnya dalam 2 (dua) surat kabar yang beredar di daerah yang bersangkutan dan/atau media massa setempat, serta tidak ada pihak yang menyatakan keberatan.

(4) Setiap janji untuk melaksanakan eksekusi Hak Tanggungan dengan cara yang bertentangan dengan ketentuan pada ayat (1), ayat (2), dan ayat (3) batal demi hukum 
(5) Sampai saat pengumuman untuk lelang dikeluarkan, penjualan sebagaimana dimaksud pada ayat (1) dapat dihindarkan dengan pelunasan utang yang dijamin dengan Hak Tanggungan itu beserta biaya-biaya eksekusi yang telah dikeluarkan.

Berdasarkan ketentuan di atas dapat dipahami bahwa eksekusi hak tanggungan berdasarkan ketentuan Pasal 20 dapat dilakukan dalam 3 (tiga) cara, yaitu : Eksekusi atas kekuasaan sendiri (Pasal 20 ayat 1 huruf a), Eksekusi berdasarkan titel eksekutorial (Pasal 20 ayat 1 huruf b), Eksekusi melalui penjualan di bawah tangan (Pasal 20 ayat 2)

Prosedur eksekusi lelang terhadap jaminan hak tanggungan menurut Undang-Undang Nomor 4 Tahun 1996 Tentang Hak Tanggungan Atas Tanah Beserta Benda-Benda yang Berkaitan dengan Tanah dapat dilihat dalam ketentuan Pasal 26. Dinyatakan dalam ketentuan Pasal 26 Undang-Undang Nomor 4 Tahun 1996 Tentang Hak Tanggungan Atas Tanah Beserta Benda-Benda yang Berkaitan dengan Tanah:

Selama belum ada peraturan perundangundangan yang mengaturnya, dengan memperhatikan ketentuan dalam Pasal 14, peraturan mengenai eksekusi hypotheek yang ada pada mulai berlakunya Undang-Undang ini, berlaku terhadap eksekusi Hak Tanggungan.

Berdasarkan ketentuan di atas, dapat dipahami bahwa selama belum ada ketentuan khusus yang mengatur tentang tata cara eksekusi hak tanggungan, maka sesuai ketentuan Pasal 26 Undang-Undang Nomor 4 Tahun 1996 Tentang Hak Tanggungan Atas Tanah Beserta Benda-Benda yang Berkaitan dengan Tanah, tata cara eksekusi hak tanggungan menggunakan peraturan mengenai eksekusi hipotik. Hal ini juga dipertegas dalam penjelasan Pasal 26 Undang-Undang Nomor 4 Tahun 1996 Tentang Hak Tanggungan Atas Tanah Beserta Benda-Benda yang Berkaitan dengan Tanah yang menyatakan:

Yang dimaksud dengan peraturan mengenai eksekusi hypotheek yang ada dalam pasal ini, adalah ketentuan- ketentuan yang diatur dalam Pasal 224 Reglemen Indonesia yang Diperbarui (Het Herziene Indonesisch Reglement, Staatsblad 1941-44) dan Pasal 258 Reglemen Acara Hukum Untuk Daerah Luar Jawa dan Madura (Reglement tot Regeling van het Rechtswezen in de Gewesten Buiten Java en Madura, Staatsblad 1927-227).

Prosedur eksekusi lelang terhadap jaminan hak tanggungan dapat dijelaskan sebagai berikut:

1. Kreditor mengajukan permohonan eksekusi hak tanggungan berdasarkan irah-irah "Demi Keadilan Berdasarkan Ketuhanan Yang Maha Esa"baik secara lisan, maupun dengan surat, kepada ketua pengadilan negeri setempat di mana objek jaminan berada. Permohonan pada umumnya dilakukan secara tertulis.

2. Setelah menerima permohonan tersebut, Ketua menyuruh panitera untuk memanggil pihak debitor (pemberi hak tanggungan) serta memperingatkan, supaya ia memenuhi kewajibannya di dalam tempo yang ditentukan oleh ketua, yang selama-lamanya delapan hari.

3. Apabila setelah lewat tempo yang ditentukan itu, dan debitor belum juga memenuhi kewajibannya, baik untuk pelunasan maupun pengosongan, atau ia jika dipanggil dengan patut, tidak datang menghadap, maka ketua oleh karena jabatannya memberi perintah dengan surat, supaya disita objek jaminan hak tanggungan untuk dilakukan penjualan melalui pelelangan umum untuk pelunasan.

Prosedur eksekusi lelang terhadap jaminan hak tanggungan menurut Undang-Undang Nomor 4 Tahun 1996 Tentang Hak Tanggungan Atas Tanah Beserta Benda-Benda Yang Berkaitan Dengan Tanah mengacu pada prosedur eksekusi hipotik sebagaimana diatur dalam Pasal 224 Reglemen Indonesia yang Diperbarui (Het Herziene Indonesisch Reglement/HIR). Pasal 224 Reglemen Indonesia yang Diperbarui (Het Herziene Indonesisch Reglement/ HIR) mengacu pada ketentuan Pasal 195, Pasal 196 serta Pasal 197 Reglemen Indonesia yang Diperbarui (Het Herziene Indonesisch Reglement/HIR).

\section{Alasan Kreditor Melelang Jaminan Hak Tanggungan Tanpa Proses Permohonan Lelang Eksekusi Ke Ketua Pengadilan Negeri}

Praktek di beberapa kreditor baik di lembaga bank maupun non bank, dalam hal debitor ternyata cidera janji, maka kreditor melakukan penjualan jaminan-jaminan hak tanggungan atas kredit yang 
macet melalui KPKNL, tanpa terlebih dahulu meminta persetujuan dari pemberi Hak Tanggungan (Debitor) dan tanpa fiat eksekusi ke Pengadilan Negeri yang berwenang. Dasar mereka melakukan penjualan langsung ke KPKNL tanpa melalui permohonan kepada Ketua Pengadilan Negeri, yaitu ketentuan Pasal 6 Undang-Undang Nomor 4 Tahun 1996 tentang Hak Tanggungan atas Tanah Beserta Benda-Benda yang Berkaitan dengan Tanah, yang menyatakan:

Apabila debitor cidera janji, pemegang Hak Tanggungan pertama mempunyai hak untuk menjual obyek Hak Tanggungan atas kekuasaan sendiri melalui pelelangan umum serta mengambil pelunasan piutangnya dari hasil penjualan tersebut.

Berdasarkan ketentuan di atas, kreditor dalam prakteknya melakukan penjualan objek jaminan hak tanggungan melalui lelang ditempuh dengan 2 (dua) alasan, yaitu:

a. Atas dasar Pasal 20 ayat (1) Undang-Undang Nomor 4 Tahun 1996 tentang Hak Tanggungan atas Tanah Beserta Benda-Benda, Lelang eksekusi Hak Tanggungan dapat dilaksanakan dengan cara Pemegang Hak Tanggungan pertama menjual objek Hak Tanggungan atas kekuasaannya sendiri melalui pelelangan sesuai Pasal 6 Undang-Undang Nomor 4 Tahun 1996 tentang Hak Tanggungan atas Tanah Beserta Benda-Benda.

b. Atas dasar Pasal 6 Undang-Undang Nomor 4 Tahun 1996 tentang Hak Tanggungan atas Tanah Beserta Benda-Benda, memberi hak kepada kreditor pemegang Hak Tanggungan pertama untuk menjual objek hak tanggungan atas kekuasaannya sendiri, apabila debitor pemberi Hak Tanggungan cidera janji (wanprestasi). Penjualan Hak Tanggungan pada dasarnya dilakukan dengan cara lelang dan tidak memerlukan fiat eksekusi dari Pengadilan Negeri, mengingat penjualan berdasarkan Pasal 6 Undang-Undang Nomor 4 Tahun 1996 tentang Hak Tanggungan atas Tanah Beserta BendaBenda ini merupakan tindakan pelaksanaan perjanjian.

\footnotetext{
Akibat Hukum Terhadap Jaminan Hak Tanggungan yang Dilelang Tanpa Proses
}

\section{Permohonan Lelang Eksekusi Ke Ketua Pengadilan Negeri}

Eksekusi jaminan atas objek Hak Tanggungan dapat dilakukan dalam hal debitor telah cidera janji atau tidak dapat memenuhi kewajibannya sebagaimana yang telah diperjanjikan dalam akta perjanjian kredit atau debitor tidak dapat melunasi utangnya meskipun kredit telah jatuh tempo dan dilanjutkan dengan lelang eksekusi hak tanggungan. Pelaksanaan lelang eksekusi hak tanggungan oleh Kantor Pelayanan Kekayaan Negara dan Lelang (KPKNL), secara umum mengacu pada Peraturan Lelang (Vendu Reglement stb 1908-189) bahwa peraturan penjualan lelang dimuka umum di Indonesia (Reglement op de openbare verkoopengen in Indonesia). Pasal 1 Peraturan Lelang (Vendu Reglement stb 1908-189) bahwa peraturan penjualan lelang dimuka umum di Indonesia (Reglement op de openbare verkoopengen in Indonesia) merumuskan bahwa penjualan dimuka umum termasuk dalam hal ini penjualan lelang dalam rangka eksekusi oleh Pengadilan Negeri harus dilakukan melalui Kantor Pelayanan Kekayaan Negara dan Lelang (KPKNL).

Prosedur lelang hak tanggungan harus melalui eksekusi lelang hak tanggungan terlebih dahulu sebelum dilakukan pelelangan umum. Hal ini ditegaskan dalam ketentuan Pasal 26 UndangUndang Nomor 4 Tahun 1996 Tentang Hak Tanggungan Atas Tanah Beserta Benda-Benda yang Berkaitan dengan Tanah yang menyatakan:

Selama belum ada peraturan perundangundangan yang mengaturnya, dengan memperhatikan ketentuan dalam Pasal 14, peraturan mengenai eksekusi hypotheek yang ada pada mulai berlakunya Undang-Undang ini, berlaku terhadap eksekusi Hak Tanggungan.

Berdasarkan ketentuan di atas, dapat dipahami bahwa selama belum ada peraturan perundangundangan yang mengatur secara khusus prosedur eksekusi hak tanggungan, maka hukum formil yang dipergunakan untuk melaksanakan eksekusi hak tanggungan adalah ketentuan mengenai eksekusi hipotik. Konsekusni logis dari ketentuan ini adalah adanya syarat mutlak untuk melaksanakan eksekusi tanggungan sesuai dengan peraturan eksekusi hipotik.

Ketentuan Pasal 6 Undang-Undang Nomor 4 
Tahun 1996 Tentang Hak Tanggungan Atas Tanah Beserta Benda-Benda yang Berkaitan dengan Tanah, dalam praktek masih menjadi perdebatan terkait dengan perlu tidaknya permohonan kepada Ketua pengadilan negeri setempat. Pasal 6 Undang-Undang Nomor 4 Tahun 1996 Tentang Hak Tanggungan Atas Tanah Beserta Benda-Benda yang Berkaitan dengan Tanah tidak secara tegas memberikan hak untuk tidak perlu meminta penetapan dari pengadilan setempat apabila akan melakukan eksekusi atas Hak Tanggungan yang menjadi jaminan utang debitor dalam hal debitor cidera janji.

Berdasarkan ketentuan Pasal 26 UndangUndang Nomor 4 Tahun 1996 Tentang Hak Tanggungan Atas Tanah Beserta Benda-Benda yang Berkaitan dengan Tanah beserta penjelasannya, dapat diketahui bahwa selama belum ada peraturan perundang-undangan yang mengatur eksekusi hak tanggungan dan dengan memperhatikan ketentuan Pasal 14 Undang-Undang Nomor 4 Tahun 1996 Tentang Hak Tanggungan Atas Tanah Beserta Benda-Benda yang Berkaitan dengan Tanah, peraturan mengenai eksekusi hipotik yang ada pada saat mulai berlakunya Undang-Undang Nomor 4 Tahun 1996 Tentang Hak Tanggungan Atas Tanah Beserta Benda-Benda yang Berkaitan dengan Tanah berlaku pula terhadap eksekusi hak tanggungan.

Berdasarkan ketentuan Pasal 26 UndangUndang Nomor 4 Tahun 1996 Tentang Hak Tanggungan Atas Tanah Beserta Benda-Benda yang Berkaitan dengan Tanah, untuk sementara sebelum ada peraturan perundang-undangan yang mengatur tentang eksekusi hak tanggungan, eksekusi hak tanggungan di dasarkan pada ketentuan Pasal 224 Reglemen Indonesia yang Diperbarui (Het Herziene Indonesisch Reglement, Staatsblad 1941-44) dan Pasal 258 Reglemen Acara Hukum Untuk Daerah Luar Jawa dan Madura (Reglement tot Regeling van het Rechtswezen in de Gewesten Buiten Java en Madura, Staatsblad 1927-227).

Pelaksanaan lelang eksekusi hak tanggungan yang tidak sesuai dengan ketentuan Pasal 224 Reglemen Indonesia yang Diperbarui (Het Herziene Indonesisch Reglement, Staatsblad 1941-44) dan Pasal 258 Reglemen Acara Hukum Untuk Daerah Luar Jawa dan Madura (Reglement tot Regeling van het Rechtswezen in de Gewesten Buiten Java en
Madura, Staatsblad 1927-227), sesuai ketentuan Pasal 26 Undang-Undang Nomor 4 Tahun 1996 Tentang Hak Tanggungan Atas Tanah Beserta Benda-Benda yang Berkaitan dengan Tanah menjadi batal demi hukum karena tidak memenuhi syarat formil sebagaimana diatur oleh Pasal 224 Reglemen Indonesia yang Diperbarui (Het Herziene Indonesisch Reglement, Staatsblad 1941-44) dan Pasal 258 Reglemen Acara Hukum Untuk Daerah Luar Jawa dan Madura (Reglement tot Regeling van het Rechtswezen in de Gewesten Buiten Java en Madura, Staatsblad 1927-227).

\section{PENUTUP}

\section{Kesimpulan}

Berdasarkan paparan pada bab sebelumnya mengenai hasil penelitian dan pembahasan dapat disimpulkan:

a. Prosedur eksekusi lelang terhadap jaminan hak tanggungan menurut Undang-Undang Nomor 4 Tahun 1996 Tentang Hak Tanggungan Atas Tanah Beserta Benda-Benda Yang Berkaitan Dengan Tanah diatur dalam ketentuan Pasal 26. Pasal 26 Undang-Undang Nomor 4 Tahun 1996 Tentang Hak Tanggungan Atas Tanah Beserta Benda-Benda Yang Berkaitan Dengan Tanah menegaskan bahwa selama belum ada peraturan perundang-undangan yang mengatur secara khusus eksekusi hak tanggunga, maka prosedur eksekusi hak tanggungan mengikuti eksekusi hipotik sebagaimana diatur dalam Pasal 224 Reglemen Indonesia yang Diperbarui (Het Herziene Indonesisch Reglement/HIR). Pasal 224 Reglemen Indonesia yang Diperbarui (Het Herziene Indonesisch Reglement/HIR). Jenis eksekusi hak tanggungan berdasarkan ketentuan Pasal 20 dapat dilakukan dalam 3 (tiga) cara, yaitu : Eksekusi atas kekuasaan sendiri (Pasal 20 ayat 1 huruf a), Eksekusi berdasarkan titel eksekutorial (Pasal 20 ayat 1 huruf b), Eksekusi melalui penjualan di bawah tangan (Pasal 20 ayat 2)

b. Alasan kreditor melelang jaminan hak tanggungan tanpa proses permohonan lelang eksekusi Ke Ketua Pengadilan Negeri, karean ada ketentuan Pasal 6 Undang-Undang Nomor 4 
Tahun 1996 tentang Hak Tanggungan atas Tanah Beserta Benda-Benda, yang memberi hak kepada kreditor pemegang Hak Tanggungan pertama untuk menjual objek hak tanggungan atas kekuasaannya sendiri, apabila debitor pemberi Hak Tanggungan cidera janji (wanprestasi).

c. Akibat hukum terhadap jaminan hak tanggungan yang dilelang tanpa proses permohonan lelang eksekusi ke Ketua Pengadilan Negeri adalah batal demi hukum. Berdasarkan ketentuan Pasal 26 Undang-Undang Nomor 4 Tahun 1996 Tentang Hak Tanggungan Atas Tanah Beserta BendaBenda yang Berkaitan dengan Tanah beserta penjelasanannya, selama belum ada peraturan perundang-undangan yang mengatur eksekusi hak tanggungan dan dengan memperhatikan ketentuan Pasal 14 Undang-Undang Nomor 4 Tahun 1996 Tentang Hak Tanggungan Atas Tanah Beserta Benda-Benda yang Berkaitan dengan Tanah, peraturan mengenai eksekusi hipotik yang ada pada saat mulai berlakunya Undang-Undang Nomor 4 Tahun 1996 Tentang Hak Tanggungan Atas Tanah Beserta BendaBenda yang Berkaitan dengan Tanah berlaku pula terhadap eksekusi hak tanggungan. Pelaksanaan lelang eksekusi hak tanggungan yang tidak sesuai dengan ketentuan Pasal 224 Reglemen Indonesia yang Diperbarui (Het Herziene Indonesisch Reglement, Staatsblad 1941-44) dan Pasal 258 Reglemen Acara Hukum Untuk Daerah Luar Jawa dan Madura (Reglement tot Regeling van het Rechtswezen in de Gewesten Buiten Java en Madura, Staatsblad 1927-227), sesuai ketentuan Pasal 26 Undang-Undang Nomor 4 Tahun 1996 Tentang Hak Tanggungan Atas Tanah Beserta Benda-Benda yang Berkaitan dengan Tanah menjadi batal demi hukum.

\section{Saran}

Pelaksanaan eksekusi hak tanggungan yang didasarkan pada ketentuan Pasal 6 Undang-Undang Nomor 4 Tahun 1996 Tentang Hak Tanggungan Atas Tanah Beserta Benda-Benda yang Berkaitan dengan Tanah tanpa melalui permohonan ke Ketua Pengadilan Negeri setempat sampai saat ini masih persoalan, oleh karena itu pemerintah perlu mengambil kebijakan hukum sebagai berikut:

a. Melakukan amandemen terhadap ketentuan Pasal 6 Undang-Undang Nomor 4 Tahun 1996 Tentang Hak Tanggungan Atas Tanah Beserta BendaBenda yang Berkaitan dengan Tanah

b. Membuat peraturan tentang ekseskusi hak tanggungan sebagaimana diamanatkan oleh Undang-Undang Nomor 4 Tahun 1996 Tentang Hak Tanggungan Atas Tanah Beserta BendaBenda yang Berkaitan dengan Tanah.

\section{DAFTAR PUSTAKA}

Buku

Bambang Sunggono,2007, Metodologi Penelitian Hukum, Rajawali Press: Jakarta.

Eugema Liliawati Mulyono,2003, Tinjauan Yuridis Undang-undang Nomor 4 Tahun 1996 tentang Hak Tanggungan Dalam Kaitannya Dengan Pemberian Kredit Oleh Perbankan, Harvarindo: Jakarta.

M.Bahsan, 2017, Hukum Jaminan dan Jaminan Kredit Perbankan Indonesia, Raja Grafindo Persada: Jakarta

Moch Anshori,Lelang Berdasarkan Pasal 6 UUHT Batal Demi Hukum, Direktur Eksekutif LPK Komnas PK-PU dan Direktur Eksekutif Entitas Hukum Indonesia, www.entitashukumindonesia.blogspot.com,

R. Soebekti, 2010, Aneka Perjanjian, Citra Aditya Bakti: Bandung, 1995

Rachmadi Usman, 2001, Aspek-Aspek Hukum Perikatan Perbankan Di Indonesia, Gramedia Pustaka: Jakarta

Soerjono Soekanto dan Sri Mamudji, 2001, Penelitian Hukum Normatif suatu Tinjauan Singkat, Radja Grafindo Persada: Jakarta

Sri Soedawi Masjchoen Sofwan,2003, Hukum Jaminan di Indonesia, Pokok-pokok Hukum Jaminan dan Jaminan Perorangan,Cetakan ke-3, Liberty Offset: Yogyakarta

Widjanarto, 2013, Hukum dan Ketentuan Perbankan Di Indonesia, Pustaka Utama Grafiti: Jakarta.

Zainuddin Ali,2010, Metode Penelitian Hukum, Sinar Grafika: Jakarta. 